\title{
Kernos
}

Revue internationale et pluridisciplinaire de religion grecque antique

18 | 2005

Varia

\section{Myth as a mobilizing force in Attic warrior society}

\section{Synnøve Des Bouvrie}

URL : http://journals.openedition.org/kernos/1524

DOI : 10.4000/kernos. 1524

ISSN : 2034-7871

\section{Éditeur}

Centre international d'étude de la religion grecque antique

\section{Édition imprimée}

Date de publication : 1 janvier 2005

Pagination : en185-201

ISSN : 0776-3824

\section{Référence électronique}

Synnøve Des Bouvrie, "Myth as a mobilizing force in Attic warrior society », Kernos [En ligne],

18 | 2005, mis en ligne le 08 juillet 2011, consulté le 19 avril 2019. URL : http://

journals.openedition.org/kernos/1524; DOI : 10.4000/kernos.1524 


\title{
Myth as a mobilizing force in Attic warrior society
}

\author{
Un bomme ne nâ̂t pas guerrier. Il le devient. \\ A man is not born a warrior. He is made so.
}

\begin{abstract}
This paper focuses on the mobilizing role of symbols and specifically on the workings of mythical theatre. Attic theatre is understood as a symbolic performance in which the comic and the tragic genres represented processes of 'over-distancing' and 'under-distancing', respectively. Instead of conceiving of tragedy as just an aesthetic or critical medium, the tragic genre is viewed as part of a complex cultural and social process that serves as a mobilizing force around the fundamental values of the polis, e.g. the warrior and his bebe. A number of cult practices are discussed in order to demonstrate the importance of warrior symbolism in Attic society. Furthermore, it is argued that the tragic performance does not present a positive and ideal image, but a violation of the social order ('the warrior'). The Children of Herakles and other tragedies are analysed in order to illustrate the argument.
\end{abstract}

Résumé : Le mythe comme force de mobilisation dans une société guerrière. L'article se concentre sur le rôle mobilisateur des symboles et en particulier sur le fonctionnement du théâtre mythique. Le théâtre attique est compris comme une performance symbolique dans laquelle le genre comique et tragique représentaient des processus de 'sur-distanciation' et de 'sousdistanciation' respectivement. Au lieu de concevoir la tragédie seulement comme un medium esthétique ou critique, le genre tragique est vu comme une part d'un processus culturel et social complexe qui sert de une force mobilisatrice autour des valeurs fondamentales de la polis, e.g. du guerrier et son hèbè. Quelques pratiques cultuelles sont discutées pour démontrer l'importance du symbolisme guerrier dans la société attique. En plus l'argument présenté est que la performance tragique ne présente pas une image positive et idéale, mais une violation de l'ordre social ('le guerrier'). Les enfants d'Héraklès et d'autres tragédies sont analysées pour illustrer cette manière de penser.

In this paper I would like to do two things: first, to treat a methodological question, and second, to offer some concrete analyses of mythical drama. With the term "myth" I refer to a so-called "traditional tale", a narrative in word or image that is recognized by a community as "our tale". Unlike Geoffrey Kirk, who has defined myth as a tale handed down from at least the former generation", I think it suffices to specify a "traditional tale" as a shared tale. In addition such a tale may become, in Walter Burkert's terminology, "eine angewandte Erzählung", a tale that is shared and applied by a community and surrounded with special attention. We may distinguish myths from folk-tales and apply "myth" to tales that carry special authority, historical

\footnotetext{
1 G.S. KIRK, Myth. Its meaning and functions in Ancient and other cultures, Berkeley / Los Angeles, 1970, p. 282.

W. BURKERT, "The organization of myth", Structure and bistory in Greek mythology and ritual, Berkeley / Los Angeles, 1979 (Sather Class. Lect., 47), p. 22 sq.
} 
or otherwise. Attic tragedy staged myth and recent history indiscriminately. Both were "our authoritative tale".

With the term "mobilizing force" I refer to some of the workings of symbols in a community, symbols understood in the sense of "key symbols" as they are identified and analysed by the anthropologist Sherry Ortner. "Key symbols" catalyse shared emotions and value orientations in a community, they may be objects of reverence as well as sources of powerful motivations 4 . Traditional or shared tales, "myths", may under certain circumstances serve as "key symbols", vehicles of core values; they may, thus, become a mobilizing force, exerting their magnetic pull on those gathered in a community.

I will identify some monuments and cults in which myth served as a "key symbol" in Ancient Greek culture, as a mobilizing force within the community of citizen-warriors. Divine and heroic personalities served of course as important mobilizing symbols, borne on religious beliefs and inhabiting shrines, images, and rituals. But mythical tales could serve this aim as well. Among these I would reckon the mythical performances of Attic tragedy. I will argue that the institution of the theatre in the classical period represented a genuine stage for symbolic performances, a space in which myths could acquire a symbolic force in Attic warrior society".

The dramatic scenes presented a "mythical universe". This universe offered no "videoclip from real life", it was moulded by multiple distortions. The tragic genre still operated in a mimetic mode, that is, it offered a serious and recognizable world, which, in contrast to comedy, respected the basic rules of nature and culture. While comedy followed the whims of chance, Thykhe, tragedy was under the austere rule of Ananke and probability. A tragedy was a bounded mythical entity, composed of an authoritative shared tale, but it manifested its own specific workings. These tragic workings and distortions are to be studied in a systematic way. We have to remind ourselves of the fact that the audience was first and foremost a collective body participating in an intense celebration. This celebration was organized as a cultural performance following a sequence of episodes, each with their own structure and workings: religious processions, sacrifice, exuberant komos, honorific ceremonies, tribal choruses with dithyrambs, polis drama - moduled in comedy, tragedy and satyr play - finally, the arbitration and evaluation of the entire event.

\footnotetext{
3 For a discussion of the concept of "myth" see S. DES BOUVRIE, "The definition of myth. Symbolic phenomena in ancient Greek culture", in ead. (ed.), Myth and symbol I. Symbolic phenomena in ancient Greek culture, Bergen, 2002 (Papers from the Norwegian Institute at Athens, 5), p. 11-69.

4 S. ORTNER, "On key symbols", American journal of anthropology 75 (1973), p. 1338, 1340; [reprinted in W.A. LESSA, E.Z. VOGT, J.M. WATANABE (eds.), Reader in comparative religion. An anthropological approach, New York, 1979, p. 93 sq.].

For a presentation of symbolic processes in traditional theater see e.g. B.E. WARD, "Not merely players. Drama, art and ritual in traditional China", Man. New series 14,1 (1979), p. 18-39. Peter Wilson points to the intense social process going on around the khoregia: P. WILSON, The Athenian institution of the khoregia. The chorus, the city and the stage, Cambridge, 2000, p. 198.
} 
Each phase required its specific expression and, we may assume, its special focus and mood.

Although we should pay attention to the entire sequence of episodes, I will concentrate on the most enigmatic and the most obviously mythical: tragedy. But I will remind of the fact that this genre should be studied within the entire celebration orchestrated into shifting focuses and moods. The specific affective quality of the total cultural performance should, then, not be neglected. This is often done, and in addition, modern scholars use to interpret tragic dramas from a modern, individualistic stance, searching for the personal views of the author and the individual reactions of the spectators. And, most seriously, they assume, as a matter of fact, beyond discussion or even consciousness, that tragic drama directed itself to the intellect and the aesthetic sensibility only. What is characteristic of this view of Greek tragedy is that it denies any absorbing involvement. Patricia Easterling seems to define the tragic performance thus: "What is represented in the theatre is both like and unlike the life it purports to imitate, like in that it offers images of the 'real world', unlike in that by definition it is make-believe" (emphasis added). Furthermore, there is the mainstream tendency to assume that the tragic genre as an expression called into question the accepted values of the community. Simon Goldhill is the most influential mouthpiece of this tendency but it is widespread ${ }^{8}$.

Goldhill, of course, built his view on Jean-Pierre Vernant, who conceived of tragic drama, I think, too much as a philosophical utterance, a kind of 1968 consciousness raising, not as an episode in a complex symbolic performance. This approach overlooks the tremendous importance of the genre's affective or cultural, creative and dynamic nature. Tragedy existed wall to wall with comic drama, a genre we without any problem recognize as a wild distortion of normality, with the aim to provoke laughter. I consider tragic drama as a comparable phenomenon: a wild distortion of normality, this time in order to provoke shock and horror?

\footnotetext{
${ }^{6}$ Patricia Easterling notices: "One of the paradoxical features of the genre is that it gives pleasure while presenting material that is always sombre, often horrifying and frightening" : P.E. EASTERLING, "Form and performance", in ead. (ed.), The Cambridge companion to Greek tragedy, Cambridge, 1997, p. 171. Another example of this approach is Nuttal who, asking "why does tragedy give pleasure?" stresses that "it is the special pleasure - the oikeia hedone - that we feel when all is done, when we have followed the sequence to its terrible end and understood. That still needs to be explained": A.D. NuTTALL, Why does tragedy give pleasure?, Oxford, 1996, p. 104 (emphasis added). Nuttall aims at finding an answer valid for ancient as well as Shakespearean tragedy.

P.E. EASTERLing, "Tragedy and ritual. "Cry "Woe, woe " but may the good prevail", Metis 2 (1988), p. 98 sq. "the crucial element of make-believe makes possible that vital paradox tragic pleasure", p. 90.

S. GoldHILL, "The Great Dionysia and civic ideology", JHS 107 (1987), p. 58-76 [reprinted in J.J. Winkier and F.I. Zeituin (eds.), Nothing to do with Dionysos, Princeton, 1990, p. 97-129].

9 I argue for this translation of eleos and phobos in Aristotle's Poetics, see note 34.
} 
Contrary to the Simon Goldhill thesis, I suppose that the celebration during the Dionysia structured and moduled the affective condition of the participants moving them from comic to tragic involvement. During the comic movement the audience was confronted with the everyday world while during the tragic movement they were separated from their mundane existence and drawn within the orbit of the authoritative world of myth.

I will refer to the anthropologists Bruce Kapferer and Don Handelman, who have discussed the way rituals may pass through different episodes: these may apply various devices transforming and transferring the audience from one mood to another ${ }^{10}$. Some devices are apt at distancing the participants and encourage their self-conscious reflection on the events, other devices draw the audience intimately into the core of the performance, absorbing them so as to loose self-awareness. Following the psychologist Thomas Scheff, Bruce Kapferer labels these shifts in mood: over-distancing and under-distancing, respectively. "A situation of under-distancing exists where individuals experience action as if it were happening to them [...]. Over-distancing [on the other hand] is present when the feelings of the audience are not engaged at all [...]. A situation of aesthetic distancing is midway between the two, and obtains where the audience experiences the emotions but is not overwhelmed by them" ${ }^{\text {.11 }}$.

Laughter is particularly apt at over-distancing, while the build-up of intimate emotional tension creates under-distancing, an absorbing attention to the super-natural world on stage. Under-distancing as well structures the relationship of those gathered into a collective body. Studying ritual performance Kapferer concludes that during the events emotions are structured into episodes with shifting moods. These episodes may range from a terrifying to a comic mood ${ }^{12}$. During the terrifying episode rythm, chant, dress, dance and stylized verbal expression create an otherwordly atmosphere drawing the participants into the realm of the sacred ${ }^{13}$. During the comic episode what is separate in normal life is "juxtaposed in absurd, impossible and unexpected ways $^{14,}$. The esoteric verbal idiom of the serious episode is contrasted with the everyday language of the market-place in the comic episode ${ }^{15}$. While communication within the serious genre is framed by a sense of "truth" and

10 B. KAPFERER, "Emotion and feeling in Sinhalese healing ritual", in id. (ed.), The power of ritual. Transition, transformation and transcendence in ritual practice, North Terrace, Adelaïde, 1984 (Special issue of Social analysis, 1 [or. 1979]), p. 153-176; D. HANDELman, "Is Naven ludic? Paradox and the communication of identity", ibid., p. 177-191.

1 KAPFERER, l.c. (n. 10), p. 170 sq. T.J. SCHEFF, "The distancing of emotion in ritual", Current anthropology 18 (1977), p. 485-486.

12 KAPFERER, l.c. (n. 10), p. 153, 157, 159

13 Ibid., p. $161 s q$

14 Ibid., p. 167.

15 Ibid., p. 161. 
imbued with moral worth, the comic inconsistencies challenge the social order $^{16}$.

The characteristics identified by Kapferer and Handelman very much fit the complex theatre celebration of Classical Athens. Considering the impressive number of visual, acoustic and verbal devices that created the distinct dramatic genres, it is obvious that Old comedy created a performance of overdistancing, that tragedy constituted a performance of under-distancing, while satyr drama may be identified as the intermediate category of "aesthetic distancing" described by Scheff and Kapferer. The whole Dionysiac celebration must, thus, be considered as a complex cultural performance, culminating in two complementary forces: comic vs. tragic, structured in a polarity of culturally conditioned responses. In the same way as, we may assume, the Attic audiences laughed at a comedy of women ruling the polis, they shuddered at a relative, a philos, left unburied to be torn by beasts and birds of prey.

Comedy was not just presented in order to portray particular situations, it was a distorted world, staged in order to create an explosion, exploding the absurd and ridiculous idea of a world upside-down. The inconsistencies shook the audience out of its cultural wits and sense of world order, and established a liminal realm of social creativity.

In a similar manner tragedy presented a stylized and distorted world in order to explode the shocking idea of a violated world order. Tragedy locked its audience into a terrifying, disrupted world that seized it in its grip. It was not just an aestetic portraiture of conflicts or a philosophical invitation to criticize.

Both genres portrayed people, but they did so in order to provoke explosions of laughter, on the one hand, and explosions of shock and horror, on the other. These provocations hinged on cultural values or symbols, as we should label them, basic institutions, roles and statuses in the community with their powerful value charge. Whatever single spectators felt and thought, or criticized, is irretrievably lost to us. And, as is emphasized by Bruce Kapferer, it is not of importance either ${ }^{17}$. As genres, these dramatic performances were designed in order to rouse certain prescribed emotions, which we can study objectively as the vis comica and the vis tragica respectively.

Goldhill's idea is briefly stated as follows: the honorific ceremonies introducing the Great Dionysia devoted massive attention to patriotic themes, first and foremost the brave warrior. Tragedy is a genre that calls into question, ergo tragic drama challenged the value of the brave warrior sacrificing himself for the benefit of the community. I doubt, however, that tragedy was an expression of critical thought and suggest a completely different model for approaching the genre.

16 B. KAPFERER, "Introduction. Ritual process and the transformation of context", in KAPFERER, o.c. (n. 10), p. 9; HaNdelman, l.c. (n. 10), p. 185-188

17 KAPFERER, l.c. (n. 10), p. 168. 


\section{Shrines and rituals}

Before I go into the details of Greek tragedy, I will concentrate on some symbolic phenomena prominent in contemporary warrior culture. We may first of all identify shrines, images, rituals and beliefs of divine and heroic powers operating as mobilizing forces in the warrior community. There were a considerable number of divine powers crucial to warfare, as Madeleine Jost has shown ${ }^{18}$. We may think of the figure of Herakles, whose cult was particularly focused on male strength and warfare ${ }^{19}$.

The Attic rite of the Oinisteria engaged the adolescent warriors in a celebration in which Herakles was the centre of attention ${ }^{20}$. At their coming of age, at the threshold of bebe, the men worshipped Herakles at four-column shrines. According to Pamphylos in Athenaios (Ath. 11.494f.), these young men about to become adult warriors offered a big bowl of wine, called oinisterion, sending it as a libation to Herakles and presenting drinks to those gathered $^{21}$. At the end of the ephebic oath Herakles is invoked in the company of Enyo, Enyalios, Ares, and Athena Areia ${ }^{22}$.

As a deeply felt symbol of warrior strength and identity Herakles might mobilize warriors and marshall them into battle. Herodotos' account of how the Athenians started their march against the Medes at the shrine of Herakles at Marathon and ended their mission at the shrine of Herakles in Kynosarges may have resonated in contemporary audiences as a significant detail explaining the course of the spectacular events ${ }^{23}$.

But we may look at the way the hero made his epiphany and came to strengthen the body of warriors before the battle at Leuktra when the

18 M. Jost, "Les divinités de la guerre", in F. Prost (ed.), Armées et sociétés de la Grèce classique, Paris, 1995, p. 163-178.

9 A. Verbanck-PIÉRARD, "Héraclès l'Athénien", in A. VERBANCK-PIÉRARD, D. Viviers (eds.), Culture et cité. L'avènement d'Athènes à l'époque archaïque. Actes du colloque intern. de Bruxelles 25-27 avril 1991, Bruxelles, 1995, p. 113 sq. In Soph., Phil., 726, Herakles is called chalkaspis, an epithet belonging to Ares (LSJ, s.v.), cf. the remarks on Thasian Herakles "gardien et militaire" (with reference to Pouilloux), by S. GEORGOUDI, "Héraclès dans les pratiques sacrificielles des cités”, in Le bestiaire d'Héraclès, Kernos Suppl. 7 (1998), p. 311.

${ }^{20}$ J. BOARDMAN, "Herakles at a columnar shrine", LIMC IV.1 (1988), p. $801 s q$; 2, p. $533 s q$

21 J. Travlos, Pictorial Dictionary of Ancient Athens, New York, 1971, p. 274-277. On the shrine of Herakles Alexikakos in Melite, O. WALTER, "Der Saülenbau des Herakles", MDAI 62 (1937), p. 48 sq.; S. WoOdFord, "Cults of Heracles in Attica", in D.G. MiTTEN, J.G. PedLey, J. Ayer SCOTT (eds.), Studies presented to George M.A. Hanfmann, Mainz, 1971, p. 213 sq., 218. Herakles and his nephew Iolaos are the center of an initiation cult in Agyrion, attested in Diodoros Siculus' age, probably presenting a much older pattern, C. JOURDAIN-ANNEQUIN, "A propos d'un rituel pour Iolaos à Agyrion. Héraclès et l'initiation des jeunes gens", in A. MOREAU (éd.), L'initiation I, Montpellier, 1992, p. 121-141.

${ }^{22}$ M.N. TOD, A selection of Greek historical inscriptions. From 403 to 323 B.C. Vol. 2, Oxford, 1948, p. 303 sq., no. 204. Although recorded in a fourth century inscription the oath is of high antiquity, ibid., p. 305.

23 As a consequence of the Battle at Marathon the Herakleia, Herakles' celebration, grew out to a major athletic event (Hdt., VI, 108, 116). In the Stoa Poikile Herakles is engaged in the battle of Marathon (Paus., I, 15, 3). 
Boiotians met the Spartans with their king Kleombrotos. In this battle the Thebans felt badly threatened by an exterior enemy, the Spartan, as well as native Boiotian enemies. In this situation they eagerly welcomed all kinds of positive signs. Xenophon tells how the Thebans were encouraged by an oracle promising the defeat of the Spartans: "at the monument of the virgins who had killed themselves after having been violated by some Lakedaimonians. The Thebans decorated the monument before the battle". And he continues: "After this it was reported that the temples were opening themselves. And a messenger told that from a shrine of Herakles the 'bopla' had disappeared, indicating that Herakles had rushed to war" (Xen., Hell. VI, 4, 7). Whether these omina are contemporary or added later to the report of the memorable battle, the story implies that armies might gain strength and confidence upon learning that mythical powers as Herakles "joined their venture". In his Anabasis Xenophon reports how he made sacrifice on his military expedition to Herakles Hegemon (Anab. VI, 2, 15, cf. VI, 5, 24; IV, 8, 2).

This confidence in the support from Herakles was early ingrained in the cultural senses of the young male. It was after all Herakles who, in the company of Hermes, coached the young males in their exercises in the gymnasion reaching the perfect state of adult male strength and vitality, $b e b e^{24}$. In funeral orations, funeral poetry and similar contexts bebe is evoked with reverence and awe. Nicole Loraux suggests that Herakles' death on the pyre followed by his marriage with Hebe visualizes the fate of the warrior. In dying in war the vital strength of the warrior, his bebe, is fixed in eternal youth $^{25}$. In the period between 420 and 380 iconography appeared on Attic vases presenting Herakles' funeral pyre with a cuirass, while Herakles disappears on a char accompanied by Athena to Olympos. Philoktetes is present carrying off his bow. According to John Boardman, this motif may have originated after the battle of Marathon, and the cuirass may allude to the hero shedding his mortality. I would add that this motif of a cuirass again suggests Herakles' military significance, as does Philoktetes carrying the bow that secured the capture of Troia ${ }^{26}$.

In Homer as well as in Attic epigraphic poetry warriors are praised for their hebe, their male vitality. E.g. in Iliad XIII, Idomeneus tells his comrades to fight against Aineias, "who is really powerful to kill men in battle; and has the bloom of male vitality (hebes anthos), which is the greatest strength". Especially when parting with life the soul of the Homeric hero is said to leave

24 L.R. FARNELL, Greek hero cults and ideas of immortality, Oxford, 1970 [orig. 1921] (The Gifford Lecture), p. 153 sq. On the pediment of the fifth century Greek temple dedicated to Apollo Sosianus, which was transferred to Rome, the two heroes join their efforts in an Amazonomachy (Musei Capitolini alla Centrale Montemartini II52).

25 N. LORAUX, "HBH et ANAPEIA. Deux versions de la mort du combattant athénien", AncSoc 6 (1975), p. 23

J. BOARDMAN, "Herakles in extremis", in E. BÖHR, W. MARTINI (eds.), Studien zur Mythologie und Vasenmalerei. Konrad Schauenburg zum 65. Geburtstag, Mainz / Rhein, 1986, p. 131. 
his manliness and male vitality (androteta kai heben) ${ }^{27}$. In inscriptions from the mid fifth century found in the Polyandria in the Kerameikos the war dead who died in defence of their fatherland are praised for having left a most honorable memorial when they sacrificed their male vitality (olesan beben) ${ }^{28}$.

Herakles was the archetypical strong-man, prepared to avert evil, the Alexikakos, and this sense of male youthful vitality is visualized in his wedding to Hebe which appears on vase paintings from the late fifth and fourth centuries" ${ }^{29}$. Annie-France Laurens has defined Hebe as "l'expression de la non-vieillesse ${ }^{30,}$. If Herakles was in love with Hebe, we may find him fighting Geras, an old decrepit creature who is attacked, humiliated and beaten by Herakles. Geras is represented on a number of vases from the first half of the fifth century, sometimes with the name TEPA $\Sigma$ inscribed $^{31}$. I have highlighted Herakles' role in warrior symbolism, but there are of course a number of divine and heroic powers inhabiting the world of the warrior and serving as a symbolic mobilizing force.

Pierre Ellinger has offered extensive analyses of the workings of Artemis and Pan in a war context, symbols evoking complex emotions and offering means of coping with critical situations so as to retain or regain collective confidence and strength under mortal military threat ${ }^{32}$.

All these instances remind us of the fact that these divine symbols are dynamic forces: they are not just expressions of thought, documents for information, and still less media for discussion. Herakles marshalled the Attic warriors into acts of courage, endurance and self-sacrifice. He certainly was felt as an interior source of confidence and a collective mobilizing force.

Such male behaviour is no innate property, it is an aspect of the ideal of manhood which is found cross-culturally, this ideal is cultivated and inculcated through elaborate social arrangements, as David Gilmore has analysed $^{33}$.

${ }^{27}$ Hom. Il. XIII, 483 sq. (Aineias), XVI, 857 (Patroklos), XXII, 363 (Hektor).

28 W. PEEK, Griechische Grabgedichte, Berlin, 1960 (Schriften und Quellen der alten Welt, 7), nos. 8, 9, 11; C. Clairmont, Patrios nomos. Public burial in Athens during the fifth and fourth centuries B.C., Oxford, 1983 (BAR Intern. Series, 161), no. 32b.

R. VOLKOMMER, Herakles in the art of classical Greece, Oxford, 1988, p. 37 sq.: "Wedding to Hebe".

30 A.-F. LAurens, "Héraklès et Hébé dans la céramique grecque ou les noces entre terre et ciel", in C. Jourdain-Annequin, C. Bonnet (eds.), 2 Rencontre Héracléenne. Héraclès, les femmes et le féminin. Actes coll. Grenoble 22-23 oct. 1992, Bruxelles / Rome, 1996, p. 239.

31 F. Brommer, "Herakles und Geras", AA 67 (1952), p. 60-73; H.A. SHAPIRO, "Geras", LIMC IV.1 (1988), p. 180 sq.; 2, p. 100 sq.; A.-F. LAURENS, "Hebe", LIMC IV.1 (1988), p. 458-464; 2, p. $275 s q$.

P. Ellinger, "Artémis, Pan et Marathon. Mythe, polythéisme et événement historique", in DES BOUVRIE (ed.), o.c. (n. 3), p. 313-332.

33 D.D. GILMORE, Manhood in the making. Cultural concepts of masculinity, New Haven / London, 1990. 


\section{Theatre}

I will now draw attention to the way mythical drama could exert a mobilizing force as well, as it appeared in the privileged moments of collective experience.

It is my contention, then, that the tragic genre, exactly like its comic counterpart, first of all was composed in order to rouse specific and powerful reactions. I will apply the term "tragic fascination" for these reactions, and try to determine their nature. We may define this "tragic fascination" as the sum of the dramatic, verbal, and rhythmic devices designed to rouse tragic reactions, parallel to the comic devices designed to rouse reactions of laughter ${ }^{34}$. Those reactions Aristotle and others labelled tragic eleos and phobos are the instant reactions of provocation when witnessing violations of cultural norms and values ${ }^{35}$. My support for this interpretation of Aristotle's definition of tragedy is his analysis in ch. 14 of the Poetics ${ }^{36}$.

Along with satyr drama, comedy and tragedy were part of a cultural performance in the sense of a collective, highly rule bound event, framed by ritual acts which separated the event from everyday life. This theatre performance was structured in a sequence of genres, and I would like to emphasize that this means that the programme was designed to guide the audience through specific sentiments ${ }^{37}$. What was characteristic of the programme was the fact that the genres were mutually contrasted. The two principal genres were in fact sharply distinguished in a polar opposition, as Oliver Taplin has underscored ${ }^{38}$. Tragedy exerted itself to the utmost to establish a credible universe, and to consolidate the sense of temporal cohesion and logical consequence ${ }^{39}$. Comedy easily dissolved the dramatic illusion, precisely in order to rouse laughter, tragedy never did, it never exposed its own theatrical nature. Despite their remote age the mythical

\footnotetext{
34 Aristotle expressed the tragic reactions in the terms eleos and phobos. These terms have generally been rendered as "pity and fear", expressions which suggest reactions following the individual personality and biography of the spectator. Such reactions, as I have mentioned, are irretrievably lost to us. I propose, on the contrary, to define Aristotle's reactions to tragic drama as "shock and horror", and to understand them as a cultural shock, a provocation of cultural norms, see S. DES BOUVRIE, "Aristotle's Poetics and the subject of tragedy", Arethusa 21 (1988), p. 54.

35 More illuminating would be a concept as "institutions", pointing to an objective state of affairs and avoiding the notion of personal moral consciousness

36 Here Aristotle emphasizes that not any act of violence will make tragedy, but violence done to a social norm (philia), in fact one of the fundamental unwritten laws in Greek society, see M. Ostwald, "Was there a concept AGRAPHOS NOMOS in Classical Greece?", in E.N. LEE, A.P.D. MOURELATOS, R.M. RORTY (eds.), Exegesis and argument. Studies in Greek philosophy presented to Gregory Vlastos, Armidale, 1973, p. 70-104. Cf. DES BOuvRIE, l.c. (n. 34).

For a thorough study of the structure of cultural events with their orchestration of sentiments see D. Handelman, Models and mirrors. Towards an anthropology of public events Cambridge, 1990, repr. 1998.

38 O. TAPLIN, "Fifth-century tragedy and comedy: A synkrisis", JHS 106 (1986), p. 163-174.

39 M. LANDFESTER, Handlungsverlauf und Komik in den frühen Komödien des Aristophanes. Untersuchungen zur antiken Literatur und Geschichte, Berlin / New York, 1977, p. 4-15.
} 
events in tragedy demanded to be taken seriously, absorbing the audience and commanding profound involvement ${ }^{40}$.

Old comedy drew the audience into a universe of implausible fantasy in which involvement was systematically cut short ${ }^{41}$. Tragedy, on the contrary, meticulously avoided improbability and indignity, inexorably forcing the fatal events upon the audience. The dramatizations in the theatre obviously served different, indeed opposite, aims, and the audience was not instructed intellectually, they were moulded affectively through the shifting workings of the successive genres.

As a profoundly serious dramatization of myth tragedy drew its authority from the religious tradition of the community ${ }^{42}$. Even though there are passages which call into question accepted views, it is my contention that they only did so superficially. In any case, such passages are in the first place utterances in character and, therefore, not necessarily the norm of the drama. More seriously, considering the level of such criticisms, it appears that tragic performances never posed questions undermining the most fundamental institutions of the community. The Medeia may voice malcontent women or expose the shallow heroism of men, but the drama does not question the necessity of continuing the family line through patrilineal succesion. Tragic characters might engage in debates about "orthodox opinion", in Bourdieu's terms, but it left "doxa" in its opaque realm of the "undiscussed ${ }^{433}$ ". What is more, it served as an instrument of charging these truths with the aura of "necessity". The most important workings of the whole tragic genre was, in my view, to valourize fundamental truths and institutions. Through its special workings the community revitalized strong commitments around central social institutions, such as the order and continuity of the oikos in its multifarious aspects as well as the warrior institution (as well as other crucial institutions), that is, the order and continuity of the polis ${ }^{44}$. Tragedy contributed to charging these "truths" with symbolic power, thus mobilizing its citizen-warrior audience into action in a fundamental way.

\footnotetext{
${ }^{40}$ An unexpected constellation, then arises: on the one hand, the world of myth in tragedy forcing belief upon the audience, and, on the other hand, the world of everyday life in comedy inviting disbelief. The qualification of "serious" events in the definition of tragedy and of its "chrestoi" - that is, serious and noble - characters point in the direction of a deeply involving dramatic performance.

${ }^{41}$ Comedy's parodies of tragedy, with their acute incongruity aimed at degrading the other genre's lofty themes, pathos sinking to bathos.

${ }^{42}$ This is forcefully argued for by C. SOURvinOu-INWOOD, Tragedy and Athenian religion, London, 2003.

43 P. Bourdieu, Outline of a theory of practice. transl. R. Nice, Cambridge, 1977 (Cambr. stud. in soc. anthrop., 16), p. 168.

44 I have argued for this point of view on several occasions, $c f$. S. DES BOuvRIE, Women in Greek tragedy. An anthropological approach, Oslo, 1990 (Symbolae Osloenses, suppl. 27), repr. 1992; ead., "Aiskhulos' Prometheus. An anthropological approach", Mètis 8, 1-2 (1993) [1996], p. 187-216; ead., "Euripides Bakkhai. An anthropological approach", CEM 48 (1997), p. 75-114.
} 
I suggest, then, that a cultural performance as the Dionysia did not just represent life and document the poet's thoughts, it transformed the community, if only for the duration of the celebration ${ }^{45}$. This transformative process was independent of the individual reactions of the participants ${ }^{46}$.

The hypothesis offered here is that the dramatic celebration constituted a ritual performance, framed by religious markers (such as processions) and the discontinuation of everyday procedures (e.g. liberation of prisoners) ${ }^{47}$. It embraced a sequence of sacrificial, ceremonial and performative phases ${ }^{48}$. The sequence of these phases transformed the participants into changing affective states $^{49}$, from solemn sacrifice through disruptive komos to polis-patriotic preplay ceremonies, subsequently phylos-patriotic dithyrambos gave way to exuberantly comic and upsetting tragic episodes assuaging in satyric display, the last phases comprising impartial judgment and communal evaluation ${ }^{50}$.

As Don Handelman has suggested, by its very organization the community moved from a competitive dithyrambic contest, splitting the polis into its constituent parts, the tribes, to a dramatic performance unifying the disjoint parts of the community ${ }^{51}$. Such an organization of the celebration guaranteed

45 KAPFERER, l.c. (n. 10), p. 157

46 KAPFERER, l.c. (n. 10), p. 153. This movement is brought about as a consequence of the performance process itself, as the members of a ritual gathering are moved from a situation of over-distancing to one of aesthetic distancing. Ibid., p. 172.

${ }^{47}$ I employ the term ritual in a loose sense being aware of Catherine Bell's and others' criticism, C. BELL, Ritual theory, ritual practice, New York / Oxford, 1992. In this case of a specific celebration clearly set apart from daily improvised and individual action, the term meets Bell's criterium for "ritualization": "I will use the term 'ritualization' to draw attention to the way in which certain social actions strategically distinguish and privilege what is being done in comparison to other, usually more quotidian, activities. A such ritualization is a matter of various culturally specific strategies for setting some activities off from others, for creating a privileging a qualitative distinction between the 'sacred' and the 'profane', and for ascribing such distincctions to realities thought to transcend the powers of human actors" (p. 74). According to Kapferer, "Ritual is a series of culturally recognized and specified events, the order of which is known in advance of their practice, and which are marked off spatially and temporally from the routine of everyday life": KAPFERER, l.c. (n. 10), p. 194

48 KAPFERER, l.c. (n. 10), p. 195. Cf. KAPFERER, o.c. (n. 10) ("Introduction"), p. 8

49 Even if only temporally: "Many rites and festivals are transformative of contexts and identitites only for the duration to their performance", KAPFERER, o.c. (n. 10), p. 13.

50 What is interesting to our inquiry is the fact that the dramatic performance shaped mythical events in the medium of tragedy and subsequently in the medium of satyr drama. Whether the medium of comedy was inserted before or after the tragedy-satyr-drama episodes is another question, the solution of which depends upon our interpretation of the comic genre; $c f$. KAPFERER, o.c. (n. 10) ("Introduction"), p. 9.

51 D. Handelman, "Designs of ritual: the City Dionysia of fifth-century Athens," in M. WEDDE (ed.), Celebrations. Sanctuaries and the vestiges of cult activity. Selected papers and discussions from the Tenth Anniversary Symposion of the Norwegian Institute at Athens, 12-16 May 1999, Papers from the Norwegian Institute at Athens, 6, Bergen, in press. "The State constructed itself as superior, judicial, and impartial in relation to its parts, the tribes [...] the lower level of tribes took apart the State symbolically, during the dithyramb contest, while this opposition was contained by the pristine impartiality of the higher State level." 
the power of the Dionysiac ritual as a polis event, the polis so recreating and revitalizing itself.

Both Kapferer and Handelman suggest that there are general properties to the serious mode of (what they label as) ritual and the hilaric mode of (what they label as) play, an opposition creating the atmosphere of "truth" and "make-belief", respectively. Contrary to the frequently held opinion that tragedy offered paradox and ambiguity, or called established truth into question, Kapferer and Handelman conclude that "ritual" phases in celebrations emphasize the validity of the moral world ${ }^{52}$, while their comic counterpart, "play", offers inconsistency subverting the social order". "Ritual" encourages a "let us believe" whereas "play" carries the meta-message "this is play ${ }^{54,}$. What these anthropologists, then, suggest is that the serious mode in cultural performance emphasizes the validity of the social world order, while it is in the comic mode they locate the phenomenon of inconsistency or paradox 55

Cultural performances may be structured by, what Handelman and Kapferer call, "symbolic types", typical characteres which mould the atmosphere in a particular phase of the performance and so transform the audience in its attitude to the events ${ }^{56}$. The category seems to manifest itself in the ludicrous and vulgar appearance of satyrs serving their specific transformative role in the audience. Symbolic types seem to belong in particular to situations of transition and ambiguity ${ }^{57}$, and we may suggest that the transition between the elevated mythical world of tragedy to the world of mundane affairs precisely offers such a condition.

I propose, then, to view tragic drama as a myth staged within an atmosphere of under-distancing, the phase within the ritual sequence in which the audience was pulled into the mythical universe, losing its self-awareness in a frightening experience. This mythical universe drew them through stages of

52 "Religious ceremonies and religious festivals are primarily affirmatory in their projects", KAPFERER, O.C. (n. 10) ("Introduction"), p. 12.

53 KAPFERER, l.c. (n. 10), p. 144, c sq. p. 145-146

54 KAPFERER, o.c. (n. 10), p. 9. "Thus communication within the ritual frame is sanctified, is imbued with moral worth, is made 'true' and is made absolute. The meta-messages of the ritual frame supercede paradox", Handelman, l.c. (n. 10), p. 185. "Play accentuates the plasticity of ideation, while ritual emphasizes the integrity of the moral community. Play has the greater capacity to comment speedily on immediate on-going fragments of social reality, while ritual tends to comment on the 'truth' or totality of structures in time and space" (p. 188).

55 I would conceive of inconsistency as the confrontation between clearly defined categories or social roles and status hierarchies, such as human and animal, master and slave, male and female.

56 On symbolic types see Handelman, l.c. (n. 10), p. 186. Cf. KAPFERER, l.c. (n. 10) ("Introduction"), p. 17

57 "According to Grathoff symbolic types are most likely to appear in contexts where ambiguity and inconsistency threaten, and their introduction forces a unity on this context. It is not surprising that symbolic types should be regular elements of rites, and particularly rites of transition, which frequently merge potentially contradictory and opposing contexts", KAPFERER, l.c. (n. 10) ("Introduction"), p. 11 
shock and horror in tragic fascination. By provoking the socio-cultural sensibilities of the audience tragic myth recharged the fundamental institutions and world order of the polis. These values were not discussed, criticized, or abolished, but revitalized and charged with new energy in the senses of the audience. In an experience of under-distancing myth operated thus as a mobilizing force in the community.

\section{The dramas}

Departing from the concept of a cultural performance, we may consider some particular tragic dramas, all manifesting the core values of the warrior. As I have argued earlier, these values are not just presented in a positive version, in the image of the ideal warrior. They are implied, presupposed as the fundamental and undiscussed basis for the continuation of the polis. In addition we have to keep in mind in what kind of world these performances manifested themselves: an exclusive, self-confident and powerful warrior society.

We may take a look at Euripides' Children of Herakles. In this drama the young and defenseless children are threatened by their father's arch-enemy, Eurystheus $^{58}$. They are committed to Iolaos' charge, who introduces himself as a former warrior and once the brother-in-arms of Herakles ${ }^{59}$. From the beginning of the drama he is presented as a man too old to be able to protect the children $^{60}$ - Herakles' sons and daughter - or their grand-mother Alkmene. During the drama Iolaos is consistenly addressed as "geron" and "presbus" ${ }^{61,}$, and his weakness and powerlessness is emphatically stressed, while the enemy's ruthless violence is underscored ${ }^{62}$. Iolaos' status as a geron is rather surprising, since he is of the same generation as Herakles' youthful children, their fathers Herakles and Iphikles being of exactly the same age. Both Alkmene and Iolaos are characterized as "old people $e^{63,}$, while according to mythical tradition Iolaos is Alkmene's grand-child. By an extraordinary distortion, then, Iolaos is presented as a deplorable old man, incapable of carrying arms ${ }^{64}$. We should ask what may be the reason for this. Herakles' children are presented as youngsters who have not yet reached their bebe $e^{65}$. Both the geron Iolaos and the paides are, then, confronted with the superior force of the enemy and their utter helplessness is highlighted by their hikesia to the Athenian king Demophon, whom they implore to protect them ${ }^{66}$.

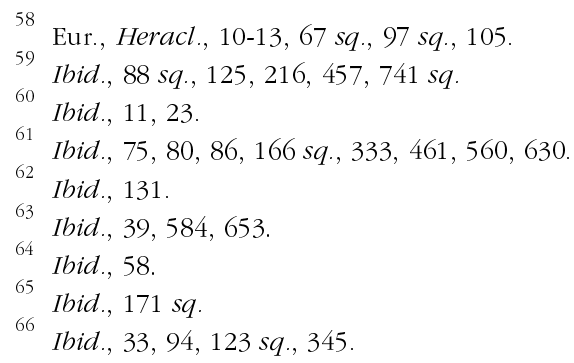


Alkmene being both aged and a woman exacerbates the situation of powerlessness. The tragedy of The children of Herakles, then, seems to turn on a fundamental value, the symbol of the warrior capable of defending his family against exterior violence. The tragic workings of the drama invert this institution, exposing the defenseless to the attacks by a brutal enemy. In a process of under-distancing the audience gathered around the tragic action, it was drawn into a disturbing event in which the young, the old, and females were threatened, eventually the whole polis came under attack. According to an oracle a noble parthenos will avert the danger of war ${ }^{67}$, and without much ado Herakles' daughter offers herself for sacrifice ${ }^{68}$. In the second half of the drama the battle is engaged, and in a miraculous transformation Iolaos is rejuvenated, regaining his warrior strength. In due time the enemy is defeated and all are saved while Eurystheus is captured and put to death.

Earlier the chorus underscores that even if Iolaos is inspired by his formidable lema, he is physically unfit for combat, his belikia refuses this and his lost bebe will not come back again ${ }^{69}$. Shortly after, however, the messenger reporting on the battle against Eurysteus and his host describes how Iolaos is no longer a geron. Significantly, Iolaos prays to Hebe and Zeus, and shortly after Herakles and Hebe appear in an epiphany. He has been transformed from geron to neos, prompting Alkmene to exclaim: this is a miracle (thaumast' elexas) $^{70}$. There is no doubt, then, that the drama presented an extraordinary development.

We should ask once more: what are the tragic workings of the drama? How are the peculiar distortions to be explained? Why is the girl's sacrifice soon forgotten? Why is Iolaos' old age emphasized, and why is he suddenly and miraculously rejuvenated? In an interpretation focusing on psychological motivation and coherence we will not find explanations to the anomalies in the drama. I doubt that the drama has been staged as an ironic expression, as has been maintained ${ }^{71}$. An approach assuming criticism of accepted values will not find much to recommend itself either. The assumption of the audience's intellectual attitude towards such dramas fails, then, to account for the peculiarities and anomalies we perceive. If we depart from our notions of proper tragedy, we will be puzzled at the happy ending as well, unless we focus upon the daughter's and Eurystheus' unhappy fate. She is, however, barely mentioned and he is elevated to cult in the aitiological cauda of the drama $^{72}$.

${ }^{67}$ Ibid., 409 sq., 488 sq.

68 Ibid., $501 \mathrm{sq}$.

69 Ibid., 702-708.

Ibid., 793-797, 852, 856 sq

A. LESKY, "On the Heraclidae of Euripides", YClS 25 (1977), p. 238; P. BuRIAN, "Euripides Heraclidae: an interpretation", CPh 72 (1977), p. 14 sq.; U. ALBINI, "La falsa convenzionalità degli Eraclide", SIFC 3. serie, 11 (1993), p. 110. sq.

${ }^{72}$ Eur., Heracl., 1030 sq. 


\section{What, then, is a tragedy?}

Seen from an anthropological perspective, the irregularities and aesthetic defects disappear. In a phase of under-distancing the audience was not asked to reflect on the motivation of the characters, nor to question the fundamental value of the warrior. It was drawn into a mythical universe, a tightly knit course of terrifying events that plunged them into a world-upside-down, in which the defenseless members of the polis were handed over to military aggression, without any proper warrior to protect them.

In the first half of the Children of Herakles the old and weak Iolaos is likewise incapable of defending the children and the role of the warrior is taken by a complete anomaly, the female child. In the second half of the drama the warrior hero is once more an anomaly, an old man who is miraculously rejuvenated. In all these cases the normal order of the warrior, an adult male performing his role properly, is violated, creating what I call an inversion, for the audience to feel horror and shock, their reaction exploding the idea of approaching war without adult males to repel the enemy. The emotional reaction, I asume, was a feeling of being provoked in one's deepseated cultural sentiments around what was natural and normal.

I will underscore that we should not conceive of tragic drama as a moralistic theatre. A moralistic drama would once again direct itself at the intellectual response of the audience, and it is my contention that the tragic explosion is a cultural reaction felt at a subliminal level of consciousness. A similar development is presented in the Iphigeneia in Aulis, the Herakles and the Trojan women, all three tragedies turning on the values of the continuation of the polis and the existence of the warrior. All dramas present an inverted world order, whether the warrior is a female or he is absent, dead or turned mad.

The Iphigeneia in Aulis has been criticized for presenting an unmotivated change of mind in the protagonist, Iphigeneia ${ }^{73}$. This psychological anomaly, however, disappears, if we conceive of the drama as another inversion of the role of the warrior. In a mood well known from the epitaphios logos the young female is presented as an ideal warrior, suddenly declaring herself prepared to die in order to defend the people of Hellas ${ }^{74}$. As if it were a state burial of the fallen, her parents are denied to dress in black and mourn ${ }^{75}$. Behaving like a warrior the would-be bride created a tragic shock implying the proper warrior in society: an adult male.

\footnotetext{
73 H.D.F. KITTO, Greek Tragedy. A literary study, London, 1966 [orig. 1939], p. 365; F. JOUAN (éd.), Euripide, Iphigenie à Aulis, Euripide Tome VII, 1, Paris, 1983, p. 35 sq.; C.E. SORum, "Myth, choice, and meaning in Euripides' Iphigenia at Aulis", AJPh 113 (1992), p. 527; R.G.A. BuXTON, "Bafflement in Greek tragedy", Metis 3 (1988), p. 41-51.

${ }_{75}$ Eur., IA, 1375 sq., 1397.

75 Eur., IA, 1437-1448
} 
The Trojan Women has been likewise criticized for lacking a plot or conflict and presenting just a parade of lamentable fates ${ }^{76}$. Still, it has been praised as the great anti-war drama and Euripides as its pacifist creator ${ }^{77}$. In the course of the drama, however, there are scenes that disprove this interpretation. Kassandra, while abominating war, glorifies him who goes to war in order to defend the polis ${ }^{78}$. Not only does Andromakhe remember her husband as the heroic warrior defending the polis ${ }^{79}$, but her son Astyanax is buried in his father's shield, while Hekabe strikes up a lament which at the same time is an intense hymn of praise to the great champion of Troia Hektor $^{80}$. Even this drama, as I interpret it, is to be conceived of as an inversion of the warrior norm, and the parade of laments of the Trojan women should not be read as a positive description of the the horrors of war. That war was horrible was obvious to the audience. But it was a fact of nature, a disaster that could not be avoided ${ }^{81}$. Contrary to the commonly held opinion that dramas like the Trojan women challenged the military values of its age, I conceive of this drama as a kind of hypothetical statement: "war is a disaster. But only if we as warriors are not there in order to prevent the outrages perpetrated on our wives and children". This reaction is not verbalized in the drama, nor was it probably brought to the consciousness of the audience of Athenian warriors. In a tragic performance of underdistancing this reaction may have remained a subliminal, and therefore all the more powerful, response, an explosion evoked in the cultural sensibility of the Athenians. Their reaction of horror at the inverted world order created shock and revitalized their crucial importance as warriors.

The Herakles itself turned once more on the symbol of the warrior, but again presenting an inverted version of the normal world order: threatened by the archetypical enemy, Lykos, Herakles' defenseless father, wife and children are in mortal danger ${ }^{82}$, while the emphatically old and weak chorus members lament their incapacity to defend them (as does the aged grandfather

76 G. PERrotta, "Le Troiane di Euripide", Dioniso 15 (1952), p. 237; A.P. BurnetT, "Trojan women and the Ganymede ode", YClS 25 (1977), p. 291; F.M. Dunn, "Reversal: Trojan women", in id. (ed.), Tragedy's end:closure and innovation in Euripidean tragedy, New York / Oxford, 1996, p. 101; D.J. CONACHER. Euripidean drama. Myth, theme and structure, Toronto, 1967, p. 137-145.

E. O'Neill Jr. called it in 1941 "a very great anti-war play": E. O'NEILL Jr., "The prologue of Euripides' Troades", TAPhA 72 (1941), p. 320. Cf. R. GoossEns, Euripide et Athènes, Bruxelles, 1962, p. 507-516; R.A.H. WATERFIELD, "Double standards in Euripides Troades", Maia 34 (1982), p. 137; P.G. MAXWELL-STUART, "The dramatic poets and the expedition to Sicily", Historia 22 (1973), p. 397; W. DESCH, "Die Hauptgestalten in des Euripides Troerinnen", GB 12-13 (1985-86), p. 65; B. MANUWALD, “Die Troerinnen' in neuem Gewand. Walter Jens, 'Der Untergang' und sein euripideisches Vorbild", AFLN 30, n.s. 18 (1987-88), p. 393-396; R. REHM, "War brides and war dead. Euripides' Troades", in Marriage into death, Princeton, 1994, p. 128.

78 Eur., Tr., $400 s q$.

79 Ibid., 590, 673, 752 sq.

${ }^{80}$ Ibid., 1137-1142, 1193-1199, $1220 s q$

81 V.D. HANSON, "The classical Greek warrior and the egalitarian ethos", AncW 31 (2000), p. 111

Eur., $H F ., 38 s q ., 454 s q ., 492 s q$ 
Amphitryon $)^{83}$. During this part of the drama the proper warrior, Herakles, is absent. During the latter part of the drama he is present, but he is struck with madness and kills his family, mistaking them for his arch enemy ${ }^{84}$. The ordinary method of interpreting this tragedy is to search for psychological and moral issues ${ }^{85}$. If we, however, approach the Herakles from an anthropological perspective, we may ask, not "why does this man act as he does?" but "what central value is inverted throughout the drama?" It will appear that the proper warrior in the Herakles should be Herakles himself, but he violates this value, either by being absent or by being mistaken in his madness about his proper object of attack.

Even though there may be passages that seem to call into question accepted norms, it is my contention that they do so only superficially. They never pose the most existential questions undermining the fundamental intitutions and values of the community. The essential function of the entire tragic genre was, in my view, to valourize social values. One of the most fundamental values was the existence of the warrior. In spite of the mythical nature of the tragic universe the audience was, as I have argued, swallowed into a performance of shock and horror, the tragic myth drawing them into the inexorable train of events under the drums of doom. Tragedy contributed to charging the value of the warrior with symbolic power and served thus as a mobilizing force in the warrior society that created this mythical performance.

Synnøve DEs BOUVRIE

Faculty of Humanities

University of Troms $\varnothing$

NO - 9037 TROMS $\varnothing$

83 Ibid., 268 sq., 436-441. Their status as "gerontes" in emphasized 126, cf. 230 sq., 326.

84 Ibid., 967-997.

85 For a sample of interpretations see U. VON WILAMOWITZ-MÖLLENDORFF, Euripides, Herakles, erklärt I, Berlin, 1895, p. 128-129; H.H.O. CHALK, "APETH and BIA in Euripides' Herakles", JHS 82 (1962), p. 7-18; J.C. KAMERBEEK, "Unity and meaning of Euripides' Heracles", Mnemosyne 19 (1966), p. 1-16; C. RucK, "Duality and the madness of Herakles", Arethusa 9 (1976), p. 53-75; K. LEE, "Human and divine in Euripides' Heracles", in Vindex humanitatis. Essays in honour of John Huntley Bishop, Armidale, 1980, p. 34-45; R. SCHLESIER, "Héraclès et la critique des dieux chez Euripide", ASNP 15 (1985), p 7-40; M.S. SILK, "Heracles and Greek tragedy", G\&R 32 (1985), p. 1-22; M. Cropp, "Heracles, Electra and the Odyssey", in M. Cropp, E. Fantham, S.E. Scully (eds.), Greek tragedy and its legacy. Essays presented to D.J. Conacher, Calgary, 1986, p. 187-199; M. PADILla, "The Gorgonic archer. Danger and sight in Euripides' Heracles", CW 86 (1992-93), p. 1-12 